\title{
STUDIES ON HYBRID RICE SEED PRODUCTION OF EGYPTIAN CYTOPLASMIC GENETIC MALE STERILE LINE SAKHA 1A / B MULTIPLICATION
}

\author{
El-Mowafi, H. F., A. A. El Gammaal, E. F. A. Arafat and W. A. \\ A. Abd Elrahman
}

ABSTRACT
Two field experiments were carried out at the Experimental Farm of Sakha Agriculture Research Station, Egypt during the two successive seasons of 2014 and 2015 to study the effect of four wind directions, northsouth (W1), west-east $\left(\mathrm{W}_{2}\right)$, north west-south east $\left(\mathrm{W}_{3}\right)$ and north east-south west $\left(W_{4}\right)$, five date of sowing intervals including $0,3,5,7$ and 9 days intervals between $A$ and their $B$ lines to get proper synchronization of flowering between the parental lines in the seed production plot and supplementary pollination during flowering period on important yield characters of hybrid rice seed production of cytoplasmic male sterile line (Sakha 1A) and their maintainer Sakha 1B) which used to produce hybrid rice seeds for EHR1,EHR2,EHR3 and other hybrids.

Asplit split plot design with four replications was used. The main plot were devoted to the four natural wind direction, north-south (W1), west-east $\left(W_{2}\right)$, north west-south east $\left(W_{3}\right)$ and north east-south west $\left(W_{4}\right)$, while the dates of sowing intervals was arranged at random in the sub plots and the supplementary pollination.

The highest $F_{1}$ seed yield (2648.2 $\mathrm{kg} \mathrm{ha}^{-1}$ and $2611.9 \mathrm{~kg} \mathrm{ha}^{-1}$ ) of CMS hybrid seed were obtained with an application of wind direction northsouth $\left(\mathrm{W}_{1}\right)$ and north east-south west $\left(\mathrm{W}_{4}\right)$, respectively.

The first date, 10 May for Sakha1A and 12, 15 May for their B with seed intervals of 3 and 5 days $\left(D_{1}\right)$ gave the maximum grain yield (2662 $\mathrm{kg}$ $\left.\mathrm{ha}^{-1}\right)$ followed by the third date (2503.9 $\left.\mathrm{kg} \mathrm{ha}^{-1}\right), 10$ May for Sakha $1 \mathrm{~A}$ and 15, 17 and 19 May for their Sakha 1B with seed intervals of 5,7 , and 9 days $\left(D_{3}\right)$.

Application of supplementary pollination $\left(S_{2}\right)$ significantly increased grain yield $\left(3034.6 \mathrm{~kg} \mathrm{ha}^{-1}\right)$ while, the lowest one was obtained without supplementary pollination.

The all possible interaction between the three factors, wind direction, date of sowing and supplementary pollination affected significantly on grain yield and the other traits which studied in both seasons.

\section{INTRODUCTION}

Rice is an important food crop of Egypt. Its production and productivity have increased substantially with the development of high yielding and early mature varieties. Recently, there has been deceleration in production growth rate of rice crop Hybrid rice technology which has made wonders in rice production in China may give similar dividends in Egypt in case the adequate quantity of quality 
seed of hybrid rice is made available at reasonable price to the farmers (El-Mowafi et al 2009). This will be possible when ambitious programme on seed production is launched involving farmers, public and private sectors in a mission mode manner (Shanker Lal (2010. The technology of hybrid rice seed production is quite different from that of maize, sorghum and pearl millet. Rice being self pollination crop. In Egypt, the yearly area cultivated annually by rice is almost more than one fifth of the total area. According to the statistics of the Ministry of Agriculture where in 2008, the total cultivated area of rice with about 1.770 .000 feddan, which produced 6.7 million tons of paddy rice with an average of $4.091 \mathrm{t} / \mathrm{fed}$. Researcher at RRTC (2008). In spite of the fact that Egypt has a high average of rice grain yield, the need to raise its productivity per unit area is a matter of importance and challenge.

Exploitation of heterosis has played a significant role in increasing productivity and production of several crops worldwide. Availability of suitable pollination control systems and the extent of out crossing between female and male parents, existence of exploitable level of heterosis and feasibility of hybrid seed production on large scale any crop( El-Mowafi et al 2006 and El-Mowafi et al 2009.

Hybrid rice technology is such one innovative breakthrough that can further increase rice production leading to food security and reduction of poverty in Egypt. Hybrid rice varieties can out yield conventional cultivars by at least $15 \%$ under the same input levels. Hence, this technology can be used to break the current yield plateau in rice, where yield levels of the conventional released cultivars have stabilized (Bastawisi et al. 2003, El Mowafi et al. 2005 and ElMowafi et al 2009).

More than 20 countries worldwide have stated hybrid rice programs and many rice hybrids have been used for commercial production, hybrid rice seed production area and yield have increased rapidly as hybrid rice growing area expanded in many countries. Seed yield in China has reached 2.5- $2.7 \mathrm{t} / \mathrm{ha}^{-1}$ and about 1- $1.5 \mathrm{t} / \mathrm{ha}^{-1}$ outside China in commercial seed production plots. The most important step from research to commercialization of production. The timely supply of cheap and good quality hybrid rice seeds from reliable channels is perquisite to the rapid expansion of hybrid rice growing area (Virmani 2003).

Success and sustenance of hybrid rice depends to a greater extent on the efficient and economic seed production technology besides the higher level of heterosis, which is a primary prerequisites. Some of the important components of seed production package, which 
need optimization are isolation distance, synchronization between parental lines, planting pattern, ideal row ratios ideal wind directions dose of applied $\mathrm{GA}_{3}$ and plant density.

The present study aimed to study the effect of wind directions application, date of sowing (Synchronization between parental lines), supplementary pollination and their interaction on some yield and its components of CMS multiplication Sakha 1A / Sakha 1B. Virmani, S. S (2003).

\section{MATERIALS AND METHODS}

Two field experiments were carried out at the Experimental Farm of Sakha Agricultural Research station, Kafr El Sheikh Governorate, Egypt, during the two successive summer seasons of 2014 and 2015. The filed experiments were conducted to study the effect of wind directions, date of sowing of parental lines and supplementary pollination during flowering period on some important yield characters of hybrid rice seed multiplication of cytoplasmic male sterile line A x B (CMS lines or A line).

The material under this study included the parental lines, Sakha 1A (female line) and their maintainer line Sakha 1B (maintainer for CMS multiplication), which used to produce many Egyptian hybrid rice combinations.

\section{Experimental design:}

A split split-plot design with four replications was used. The main plots were devoted to the four natural wind direction north-south (W1 ), west-east $\left(\mathrm{W}_{2}\right)$, north west-south east $\left(\mathrm{W}_{3}\right)$ and north eastsouth west $\left(W_{4}\right)$, while the dates of sowing intervals $\left(D_{1}\right),\left(D_{2}\right),\left(D_{3}\right)$, $\left(D_{4}\right)$ and $\left(D_{5}\right)$ were arranged at random in the sub plots (Table 1) and the supplementary pollination.

\section{Cultural practices:}

Rice seed at the rate of $20 \mathrm{~kg} / \mathrm{ha}^{-1}$ (15 kg of Sakha 1 A+ $5 \mathrm{~kg}$ of Sakha 1B for each line) IR69625A and their maintainer line IR69625B were soaked in fresh water for 24 hours then drained and incubated for 48 hours to hasten early germination.

The pre-germinated seed was uniformly broadcasted in the nursery on six dates for Sakha $1 \mathrm{~B}$ line on $10^{\text {th }}, 12^{\text {th }}, 15^{\text {th }}, 17^{\text {th }}, 19^{\text {th }}$, and $22^{\text {th }}$ May 2014 and 2015 seasons to provide adequate pollen load to male sterile line IR69625A which was sown May $10^{\text {th }}$ and $22^{\text {th }}$ of 2014 and 2015 seasons, respectively (Table 1), to get complete synchronization of flowering based on the growth duration in the previous seasons that was $98 \pm 3$ days of Sakha $1 \mathrm{~A}$ line, and $95_{ \pm}$ 4days for Sakha 1B line(Sakha 1B earlier 3 days befor Sakha 1A). 
Table (1): Sowing date of $A$ and their $B$ line under study

\begin{tabular}{|c|c|c|c|}
\hline Application & A line & B line & Differences \\
\hline \hline$D_{1}$ & 10 May & 12,15 May & 3,5 days \\
\hline$D_{2}$ & 10 May & 15,17 May & 5,7 days \\
\hline$D_{3}$ & 10 May & $15,17,19$ May & $5,7,9$ days \\
\hline$D_{4}$ & 10 May & 10 May & Same day \\
\hline$D_{5}$ & 22 May & 22 May & Same day \\
\hline
\end{tabular}

Table (2): Optimum package of recommendations for hybrid rice seed production (AXR) and CMS multiplication (AXB)

\begin{tabular}{|c|c|}
\hline Operation & Particulars \\
\hline Sowing date & April 25- May 15 \\
\hline Seed rate & $\begin{array}{l}\text { Seed parent : } 27-36 \mathrm{~kg} / \mathrm{ha} \\
\text { Pollen parent: } 9-12 \mathrm{~kg} / \mathrm{ha}\end{array}$ \\
\hline Nursery & $\begin{array}{l}\text { Sparse seeding }\left(24-57 \mathrm{~g} / \mathrm{m}^{2}\right) \text { to ensure seedlings } \\
\text { with } 3 \text { tillers in } 25 \text { days }\end{array}$ \\
\hline Row ratio & $8 \mathrm{~A}$ line : $2 \mathrm{~B}$ line \\
\hline Spacing & $\begin{array}{l}\text { Male : male } 30 \mathrm{~cm} \\
\text { Male : female } 20 \mathrm{~cm} \\
\text { Female : female } 15 \mathrm{~cm} \\
\text { Plant : plant } 15 \mathrm{~cm}\end{array}$ \\
\hline $\mathrm{GA}_{3}$ application (BErLEX) & $\begin{array}{l}300 \mathrm{~g} / \mathrm{ha} \text { in } 500 \text { liters of water at } 10 \% \text { of heading in } \\
\text { two split doses of } 40 \% \text { and } 60 \% \text { in consecutive days }\end{array}$ \\
\hline Supplementary pollination & $\begin{array}{l}3-4 \text { times a day at peak of anthesis time with } 30 \\
\text { minutes interval }\end{array}$ \\
\hline
\end{tabular}

Row ratio and planting patterns: Row ratio refers to the ratio of male rows to female rows

The Row ratio of female (A line) and The row ratio of female ( $\mathrm{A}$ line) and $\mathrm{B}$ (maintainer line) parent is kept 8:2.

\section{Spacing and method of transplanting:}

The spacing between various parents should be as follows:

-Male : Male $=30 \mathrm{~cm}$

-Male : Female $=20 \mathrm{~cm}$

- Female : Female $=15 \mathrm{~cm}$

-plant : plant $=15 \mathrm{~cm}$

At each hill, two seedlings should transplanted at the age of 25:30 days. The transplanting of older seedling delays flowering, whereas for younger seedlings flowering occurs in advance. 


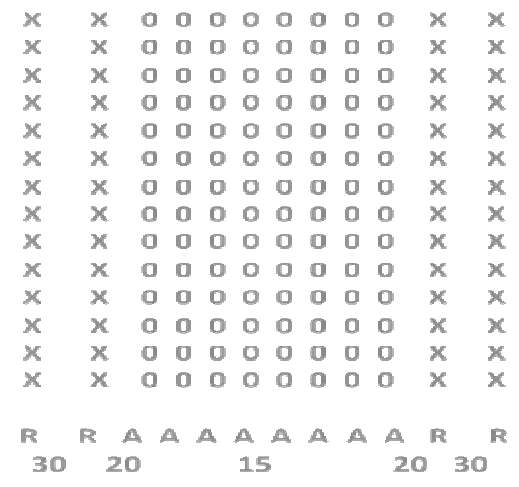

North-south
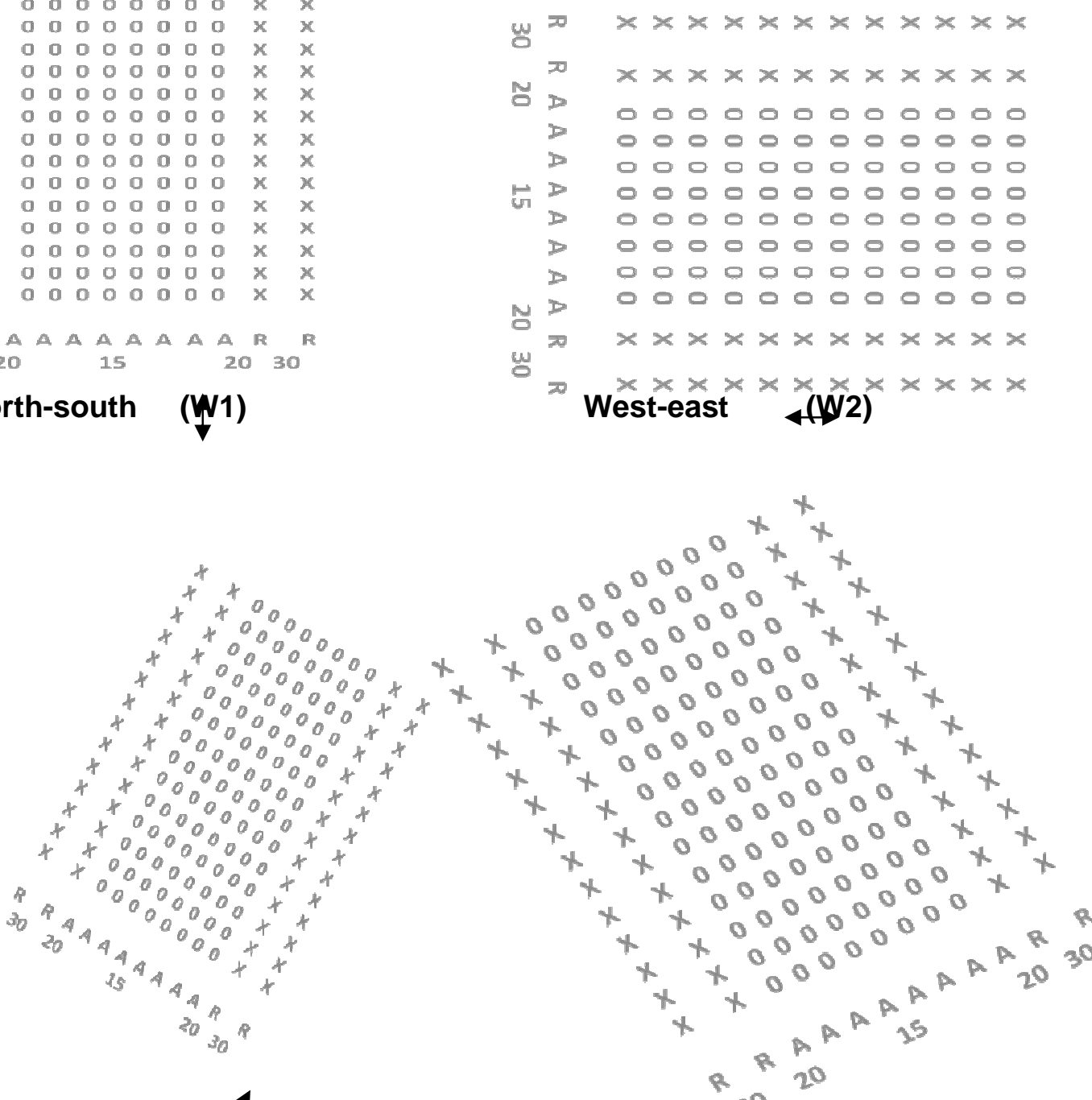

North east-south west

$\left(\mathrm{W}_{4}\right)$

North Ŵest-south

east $\left(\mathrm{W}_{3}\right)$

Fig: Planting pattern for hybrid seed production with a B/A row ratio of $2: 8$

0 : A line

$X$ : B line

Pattern of transplanting for parental lines:

Working alley distance was $30 \mathrm{~cm}$, while the distance between rows of male parent was $30 \mathrm{~cm}$, and $15 \mathrm{~cm}$ among hills within rows. The distance between EM-IB rows (B line) to the next row of IR69625A (Female parent) was $20 \mathrm{~cm}$. The direction of transplanting of male to female rows were perpendicular to the prevailing four wind direction at heading $(A \times B)$ stage in both seasons.

\section{North}




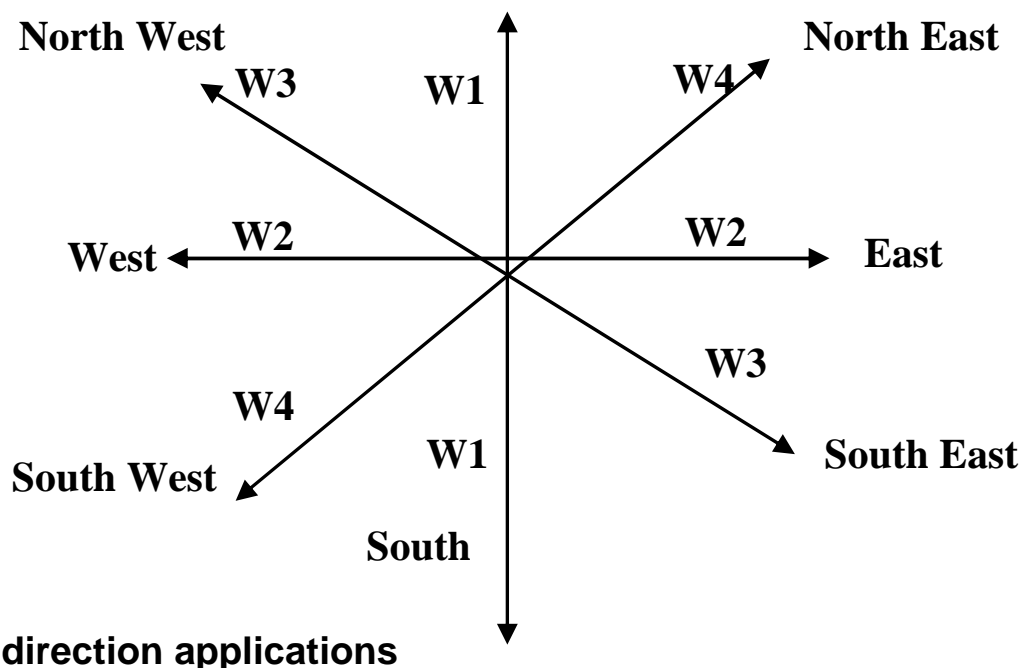

Fig 1: Wind direction applications

The weeds were chemically controlled using Thiobencarb $50 \%$ at the rate of $2 \mathrm{~L} / \mathrm{fed}$, mixed with enough sand to make it easy for homogenous distribution. It was applied seven days after sowing in the nursery and four days after transplanting into $3 \mathrm{~cm}$ water depth and kept without either flushing or irrigation until all the water in the filed was absorbed to increase the efficiency of the herbicide to control weeds. The other usual practices were conducted as recommended in growing rice fields.

\section{Synchronization of flowering:}

Determination of growth duration from seeding to flowering was used for Sakha $1 \mathrm{~A}$ and their maintainer Sakha 1B line to adjust flowering date between both parents in both seasons.

\section{Supplementary pollination:}

Supplementary pollination is artificially carried out by shaking the canopy of the pollen parent at flowering by rope or bamboo stick to increase cross pollination (Virmani and Sharma 1993)

\section{Methods of Supplementary Pollination}

Supplementary pollination is done by:

1- Two persons pulling a $1-\mathrm{cm}$ diameter rope along the two $\mathrm{B}$ or $\mathrm{R}$ lines.

2- One person stirring the canopy layer of the $B$ or $R$ lines with a bamboo stick or rope, taking care not to break off the panicles at the neck. 
Generally, supplementary pollination is carried out at 30 min intervals for five times daily both morning and evening during peak anthesis (1012 am and 2-4 pm) until no pollen remains on the $B$ or $R$ lines. It is not needed than moderate breeze.

\section{Timing of Supplementary Pollination:}

Supplementary pollination is done on calm days when wind speed is so low $(1-3 \mathrm{~km} / \mathrm{hr}$ ) that is causes little or no movement of the crop canopy. Wind speed that low is not enough to dispeers pollen nuformally to the seed parent.

If there is enough wind $(8-10 \mathrm{~km} / \mathrm{hr})$ to cause moderate movement in the crop canopy, supplementary pollination is not needed.

-Begin supplementary pollination in the morning, but not before the seed parent is blooming, begin as soon as the florets of the pollen parent begin to open.

-Stir the canopy every 30 min until all blooming florets in the pollen parent are closed.

-continue supplementary pollination even after the florets of the seed parent have closed, because exerted stigma are still respective to pollen.

\section{Studied characters:}

The data were recorded according to standard evaluation system of IRRI 1996, for all studied characters, grain yield (t/ha), filled grains panicle $^{-1}$, seed set $\%$ and 1000 -grain wheight.

\section{Statistical analysis:}

All data collected, were subjected to analysis of variance according to Gomez and Gomez (1984). All statistical analysis was performed using and analysis of variance technique by means of "IRRISTAT" computer software package. Treatment means were compared by Duncan's multiple range test (Ducan, 1955).

\section{RESULTS AND DISCUSSION}

The results obtained from the present investigation in the two successive seasons of 2014 and 2015 are presented and discussed as follow: Tables $\left(3,4,5\right.$, and 6) presents grain yield $\left(\mathrm{kg} / \mathrm{ha}^{-1}\right)$, filled grains panicle ${ }^{-1}$, seed set percentage and 1000-grain weight as affected by wind direction, date of sowing and supplementary pollination as well as their interaction during in 2014 and 2015 seasons.

\section{Effect of wind directions:}

Data presented in Tables $(3,4,5$, and 6$)$ asserted that highly significant differences were recorded between different wind direction on grain yield ( $\mathrm{t} / \mathrm{ha})$ in the two studied seasons. Within various wind direction wind direction 1 (W1) and wind direction 4 (W4) showed 
statistically excessive superiority in all four studied characters compared with the rest of wind directions in two seasons of study. These results may be due to the fact that applied true wind direction produced higher number of filled grains panicle ${ }^{-1}$ maximum seed setting percentage and heavier 1000 grain weight, which consequently gave higher grain yield.

The highest out-crossing may be attained if the row direction is adjusted nearly perpendicular to the wind direction prevailing at the time of flowering.

Effect of sowing date:

Synchronization of flowering of male and female parents ensures higher hybrid rice seed yield. However, normally in most of the hybrid rice combinations the parental lines differ in flowering. Synchronization in flowering can be attained by measure seeding interval. The parental lines differing in their growth duration can be sown on staggered dates in the nursery beds, so that they come to flowering at the same time in the main field where hybrid seed is to be produced. Pollen parent is sown in two or three splits i.e., 3,5 and 7 days after sowing of $A$ line.

The average of grain yield $\left(\mathrm{kg} \mathrm{ha}^{-1}\right)$ was significantly affected by date of sowing in both seasons, Table (4). The first date (D1) gave the maximum grain yield (2705.8 and $2618.2 \mathrm{~kg} \mathrm{ha}^{-1}$ ) followed by the third date (D3) which gave (2545.2 and $2462.7 \mathrm{~kg} / \mathrm{ha}$ ) in the first and second season, respectively. Whereas the minimum grain yield $(2214.4$ and $2129.7 \mathrm{~kg} / \mathrm{ha})$ was produced by the fourth date in both seasons, respectively. However, Data in Table (4) reveal that grains panicle $^{-1}$ significantly affected filled grains panicle ${ }^{-1}$ in the two seasons. The dates of sowing (D1 and D2) resulted in higher grains panicle-1 in both seasons while the date of sowing (D4) and (D5) gave the lowest in 2014 and 2015 seasons, respectively.

Synchronization of flowering caused a significant increase in percentage of out-crossing (seed set \%), Table (5). The date of sowing 3 (D3) gave the maximum of out-crossing rate (22.35 and $22.24 \%)$ in both seasons, respectively. On the other hand, the date of sowing 4 (D4) gave the minimum of out-crossing rate (18.74 and 18.68\%) in the two seasons, respectively.

The results in Table (6) reveal that dates of sowing were significantly affected on 1000-grain weight range of (22.90 to 23.22 and 22.94 to $23.27 \mathrm{~g}$ ) in both seasons respectively. D2 gave the heavier grains followed by D3 and D1, while D4 recorded the lowest value of 1000-grain weight in the two seasons. This findings in conformity with those reported by Viraktamath (1995a) and (1995b), Viraktamath and Ramesha (1996). 
Table 3: Grain yield $\left(\mathrm{kg} \mathrm{ha}^{-1}\right)$ as affected by wind direction sources, date of sowing and supplementary pollination at flowering as well as their interactions in 2014 and 2015 seasons

\begin{tabular}{|c|c|c|c|}
\hline \multirow{2}{*}{ Treatments } & \multicolumn{2}{|c|}{ Grain yield kg ha $^{-1}$} & \multirow{2}{*}{ Mean } \\
\hline & 2014 & 2015 & \\
\hline $\begin{array}{l}\text { Wind direction } \\
\qquad \begin{array}{l}W_{1} \\
W_{2} \\
W_{3} \\
W_{4} \\
\end{array}\end{array}$ & $\begin{array}{l}2684.6 \\
2110.6 \\
2319.3 \\
2658.9\end{array}$ & $\begin{array}{l}2611.8 \\
2029.0 \\
2224.6 \\
2565.0 \\
\end{array}$ & $\begin{array}{l}2648.2 \\
2069.8 \\
2271.9 \\
2611.9\end{array}$ \\
\hline F. test & $* *$ & $\star \star *$ & \\
\hline L.S.D. 0.05 & 156.1 & 22.97 & \\
\hline $\begin{array}{r}\text { Date of sowing } \\
D_{1} \\
D_{2} \\
D_{3} \\
D_{4} \\
D_{5} \\
\end{array}$ & $\begin{array}{l}2705.8 \\
2523.1 \\
2545.2 \\
2214.4 \\
2228.1\end{array}$ & $\begin{array}{l}2618.2 \\
2431.5 \\
2462.7 \\
2129.7 \\
2145.9 \\
\end{array}$ & $\begin{array}{l}2662.0 \\
2477.3 \\
2503.9 \\
2172.1 \\
2187.0 \\
\end{array}$ \\
\hline F. test & ** & ** & \\
\hline L.S.D. 0.05 & 126.7 & 26.56 & \\
\hline $\begin{array}{r}\text { Supplementary } \mathrm{P} . \\
\mathrm{S}_{1} \\
\mathrm{~S}_{2} \\
\end{array}$ & $\begin{array}{l}1808.1 \\
3078.6\end{array}$ & $\begin{array}{l}1724.6 \\
2990.6 \\
\end{array}$ & $\begin{array}{l}1766.4 \\
3034.6\end{array}$ \\
\hline F. test & ** & ** & \\
\hline L.S.D. 0.05 & 82.0 & 16.90 & \\
\hline $\begin{array}{r}\text { Interaction } \\
W \times D \\
W \times S \\
S \times D \\
W \times D \times S \\
\end{array}$ & $\begin{array}{l}* * \\
* * \\
* * \\
* * \\
* * \\
\end{array}$ & $\begin{array}{l}\star \star \\
\star \star \\
* \star \\
* \star \\
\end{array}$ & \\
\hline
\end{tabular}

${ }^{*},{ }^{* *}$ Significant at 0.05 and 0.01 levels, respectively. 
Table 4: Filled grains panicle ${ }^{-1}$ as affected by wind direction sources, date of sowing and supplementary pollination at flowering as well as their interactions in 2014 and 2015 seasons

\begin{tabular}{|c|c|c|c|}
\hline \multirow{2}{*}{ Treatments } & \multicolumn{2}{|c|}{ Filled grains panicle $^{-1}$} & \multirow{2}{*}{ Mean } \\
\hline & 2014 & 2015 & \\
\hline $\begin{array}{l}\text { Wind direction } \\
\qquad \begin{array}{l}W_{1} \\
W_{2} \\
W_{3} \\
W_{4} \\
\end{array}\end{array}$ & $\begin{array}{l}44.89 \\
34.87 \\
38.87 \\
44.16 \\
\end{array}$ & $\begin{array}{l}42.05 \\
36.43 \\
37.36 \\
39.43 \\
\end{array}$ & $\begin{array}{l}43.47 \\
35.65 \\
38.12 \\
41.80 \\
\end{array}$ \\
\hline F. test & ** & ** & \\
\hline L.S.D. 0.05 & 1.617 & 0.83 & \\
\hline $\begin{array}{r}\text { Date of sowing } \\
D_{1} \\
D_{2} \\
D_{3} \\
D_{4} \\
D_{5} \\
\end{array}$ & $\begin{array}{l}41.09 \\
42.10 \\
42.29 \\
36.37 \\
41.65 \\
\end{array}$ & $\begin{array}{l}42.84 \\
40.20 \\
39.64 \\
37.06 \\
34.34 \\
\end{array}$ & $\begin{array}{l}41.97 \\
41.15 \\
40.97 \\
36.72 \\
37.97 \\
\end{array}$ \\
\hline F. test & *夫 & *夫 & \\
\hline L.S.D. 0.05 & 1.991 & 0.96 & \\
\hline $\begin{array}{r}\text { Supplementary } \mathrm{P} . \\
\mathrm{S}_{1} \\
\mathrm{~S}_{2}\end{array}$ & $\begin{array}{l}30.91 \\
50.56\end{array}$ & $\begin{array}{l}29.86 \\
47.77\end{array}$ & $\begin{array}{l}30.39 \\
49.17\end{array}$ \\
\hline F. test & ** & ** & \\
\hline L.S.D. 0.05 & 1.233 & 0.59 & \\
\hline $\begin{array}{l}\text { Interaction } \\
W \times D \\
W \times S \\
S \times D \\
W \times D \times S \\
\end{array}$ & $\begin{array}{l}* * \\
* * \\
* * \\
* * \\
* * \\
\end{array}$ & $\begin{array}{l}* * \\
* * \\
* * \\
* * \\
\end{array}$ & \\
\hline
\end{tabular}

${ }^{*},{ }^{* *}$ Significant at 0.05 and 0.01 levels, respectively.

Table 5: Seed set percentage \% as affected by wind direction sources, date of sowing and supplementary pollination at flowering as well as their interactions in 2014 and 2015 seasons

\begin{tabular}{||c||c|c|c||}
\hline \multicolumn{1}{|c||}{ Treatments } & \multicolumn{2}{c|}{ Seed set \% } & \multirow{2}{*}{ Mean } \\
\cline { 2 - 3 } & $\mathbf{2 0 1 4}$ & $\mathbf{2 0 1 5}$ & \\
\hline \hline Wind direction & & & \\
$\mathrm{W}_{1}$ & 22.37 & 21.89 & 22.13 \\
$\mathrm{~W}_{2}$ & 18.37 & 18.62 & 18.50 \\
$\mathrm{~W}_{3}$ & 20.17 & 19.92 & 20.05 \\
$\mathrm{~W}_{4}$ & 22.75 & 22.32 & 22.24 \\
\hline F. test & $\star \star$ & & \\
\hline L.S.D. 0.05 & 1.684 & 0.49 & \\
\hline Date of sowing & & & \\
$\mathrm{D}_{1}$ & 21.78 & 21.37 & 21.58 \\
$\mathrm{D}_{2}$ & 21.82 & 21.50 & 21.66 \\
$\mathrm{D}_{3}$ & 22.35 & 22.24 & 22.30 \\
$\mathrm{D}_{4}$ & 18.74 & 18.68 & 18.71
\end{tabular}




\begin{tabular}{|c|c|c|c|}
\hline$D_{5}$ & 19.88 & 19.56 & 19.72 \\
\hline F. test & ** & $\star \star *$ & \\
\hline L.S.D. 0.05 & 1.494 & 0.68 & \\
\hline $\begin{array}{r}\text { Supplementary } \mathrm{P} . \\
\mathrm{S}_{1} \\
\mathrm{~S}_{2}\end{array}$ & $\begin{array}{r}15.64 \\
26.19 \\
\end{array}$ & $\begin{array}{l}15.42 \\
25.96\end{array}$ & $\begin{array}{l}15.53 \\
26.08 \\
\end{array}$ \\
\hline F. test & ** & -- & \\
\hline L.S.D. 0.05 & 1.077 & 0.45 & \\
\hline $\begin{array}{l}\text { Interaction } \\
W \times D \\
W \times S \\
S \times D \\
W \times D \times S\end{array}$ & $\begin{array}{l}\text { ** } \\
\star \star \\
\star \star \\
\star *\end{array}$ & $\begin{array}{l}* * \\
* * \\
* * \\
* *\end{array}$ & \\
\hline
\end{tabular}

${ }^{\star},{ }^{\star *}$ Significant at 0.05 and 0.01 levels, respectively.

Table 6: 1000-grain weight $(\mathrm{g})$ as affected by wind direction sources, date of sowing and supplementary pollination at flowering as well as their interactions in 2014 and 2015 seasons

\begin{tabular}{|c|c|c|c|}
\hline \multirow{2}{*}{ Treatments } & \multicolumn{2}{|c|}{$\overline{1000-g r a i n ~ w e i g h t ~}$} & \multirow{2}{*}{ Mean } \\
\hline & 2014 & 2015 & \\
\hline $\begin{array}{l}\text { Wind direction } \\
\qquad \begin{array}{l}W_{1} \\
W_{2} \\
W_{3} \\
W_{4}\end{array}\end{array}$ & $\begin{array}{l}23.52 \\
22.59 \\
23.05 \\
23.38 \\
\end{array}$ & $\begin{array}{l}23.56 \\
22.56 \\
23.06 \\
23.36\end{array}$ & $\begin{array}{l}23.54 \\
22.58 \\
23.06 \\
23.37\end{array}$ \\
\hline F. test & $\star \star$ & ** & \\
\hline L.S.D. 0.05 & 0.04 & 0.06 & \\
\hline $\begin{array}{r}\text { Date of sowing } \\
D_{1} \\
D_{2} \\
D_{3} \\
D_{4} \\
D_{5} \\
\end{array}$ & $\begin{array}{l}23.21 \\
23.19 \\
23.22 \\
22.90 \\
23.15 \\
\end{array}$ & $\begin{array}{l}23.17 \\
23.27 \\
23.19 \\
22.94 \\
23.11 \\
\end{array}$ & $\begin{array}{l}23.19 \\
23.23 \\
23.21 \\
22.92 \\
23.13 \\
\end{array}$ \\
\hline F. test & ** & ** & \\
\hline L.S.D. 0.05 & 0.05 & 0.07 & \\
\hline $\begin{array}{r}\text { Supplementary } \mathrm{P} . \\
\mathrm{S}_{1} \\
\mathrm{~S}_{2} \\
\end{array}$ & $\begin{array}{l}22.77 \\
23.51 \\
\end{array}$ & $\begin{array}{l}22.79 \\
23.48 \\
\end{array}$ & $\begin{array}{l}22.53 \\
23.50 \\
\end{array}$ \\
\hline F. test & ** & ** & \\
\hline L.S.D. 0.05 & 0.03 & 0.04 & \\
\hline $\begin{array}{r}\text { Interaction } \\
W \times D \\
W \times S \\
S \times D \\
W \times D \times S \\
\end{array}$ & $\begin{array}{l}* * \\
\star * \\
\star * \\
\star * \\
* * \\
\end{array}$ & $\begin{array}{l}* * \\
* * \\
* * \\
* * \\
\end{array}$ & \\
\hline
\end{tabular}

${ }^{*},{ }^{* *}$ Significant at 0.05 and 0.01 levels, respectively. 


\section{Effect of supplementary pollination:}

Rice is self-pollinated crop and hence there is need for supplementary pollination for enhancing out-crossing and increasing hybrid seed yield. In this operation, the pollen parent plants are shaken, which helps in shedding and dispersal of pollen grains over the $A$ line. This can be done either by rope polling or by shaking the pollen $p$ [aren't with the help of two bamboo sticks. The first supplementary pollination should be done at peak anthesis time when 30 to $40 \%$ of the spiklets are open and anthers are fully exerted. This process is repeated three to five times during the day at an interval of $30 \mathrm{~min}$. This process should be done for 7-10 days during flowering period.

The analysis of variance indicated that grain yield $\left(\mathrm{kg} \mathrm{ha}^{-1}\right)$ was significantly influenced by supplementary pollination in the two seasons of study Table (4). Application supplementary pollination $\left(\mathrm{S}_{2}\right)$ gave the highest grain yield (3078.6 and $2990.6 \mathrm{~kg} / \mathrm{ha}$ ), while the lowest grain yield ( 1808.1 and $1724.6 \mathrm{~kg} \mathrm{ha}^{-1}$ ) was obtained by the control treatment (without supplementary pollenation) in both seasons, respectively. However, filled grains panicle ${ }^{-1}$, seed set percentage and 1000-grain weight significantly increased by supplementary pollination(S2) and gave the highest filled grains panicle ${ }^{-1}$, Seed set percentage and 1000-grain weight while control (supplementary pollination S1) gave the lowest values.

\section{Interaction effect:}

The all possible interactions between or among the three factors under study, wind direction, date of sowing and supplementary pollination had a significant effects on all four studied characters in the two seasons, Tables (3,4,5 and 6).

Data presented in Table (7) show the highest grain yield (3224.3 and $3161.9 \mathrm{~kg} / \mathrm{ha}$ ) with the wind direction 1 (W1) and first date of sowing (D1), while the wind direction 2 (W2) and date of sowing 4 (D4) gave the lowest grain yield (1808.5 and $1730.0 \mathrm{~kg} / \mathrm{ha}$ ) in both seasons, respectively.

Data implied in Table (7) demonstrated that, highly significant differences were recorded between four wind directions and various sowing date intervals application in terms of filled grains panicle-1, grain yield (t/ha), seed set percentage and1000-grain weight $(\mathrm{g})$ in both seasons of study. The data presented in Table ( 7 ) reveal that all the four studied characters were higher when rice plants treated by wind direction (W1) and sowing dates (D1, D2 and D3) followed by wind direction (W4) and dates of sowing (D2 and D3). On the other 
hand, the wind direction (W2) with all dates of sowing and wind direction (W3) with the dates of (D1, D4 and D4) gave the lowest values.

Date presented in Table (8) reveal that the highest grain yield, filled grains panicle- 1 , seed set $\%$ and1000-grain weight were obtained when wind direction one (W1), followed by (W4) then (W4) applied with supplementary pollination (S2). It is also clear form the same table that the lowest grain yield was resulted from the wind direction two (W2) with no supplementary pollination (S2) in both seasons, respectively.

According to date presented in Table (9) it is clear that the maximum grain yield ( 3408.9 and $3315.0 \mathrm{~kg} / \mathrm{ha}$ ) was obtained when CMS line and their maintainer grown at he first date (D1) under supplementary pollination (S2), while the minimum one was produced by the fourth date with no supplementary pollination (S1) in the two seasons, respectively. The highest values of grain yield, filled grains panicle, seed set $\%$ and 1000 -grain weight were obtained from the dates of D1,D2 and D3 with supplementary pollination (S2) 
Table 7: Grain yield (t ha ${ }^{-1}$ ), filled grains panicle ${ }^{-1}$, 1000-grain weight (g) and seed set percentage (\%) as affected by the interaction between date of sowing and wind direction in 2014 and 2015 seasons

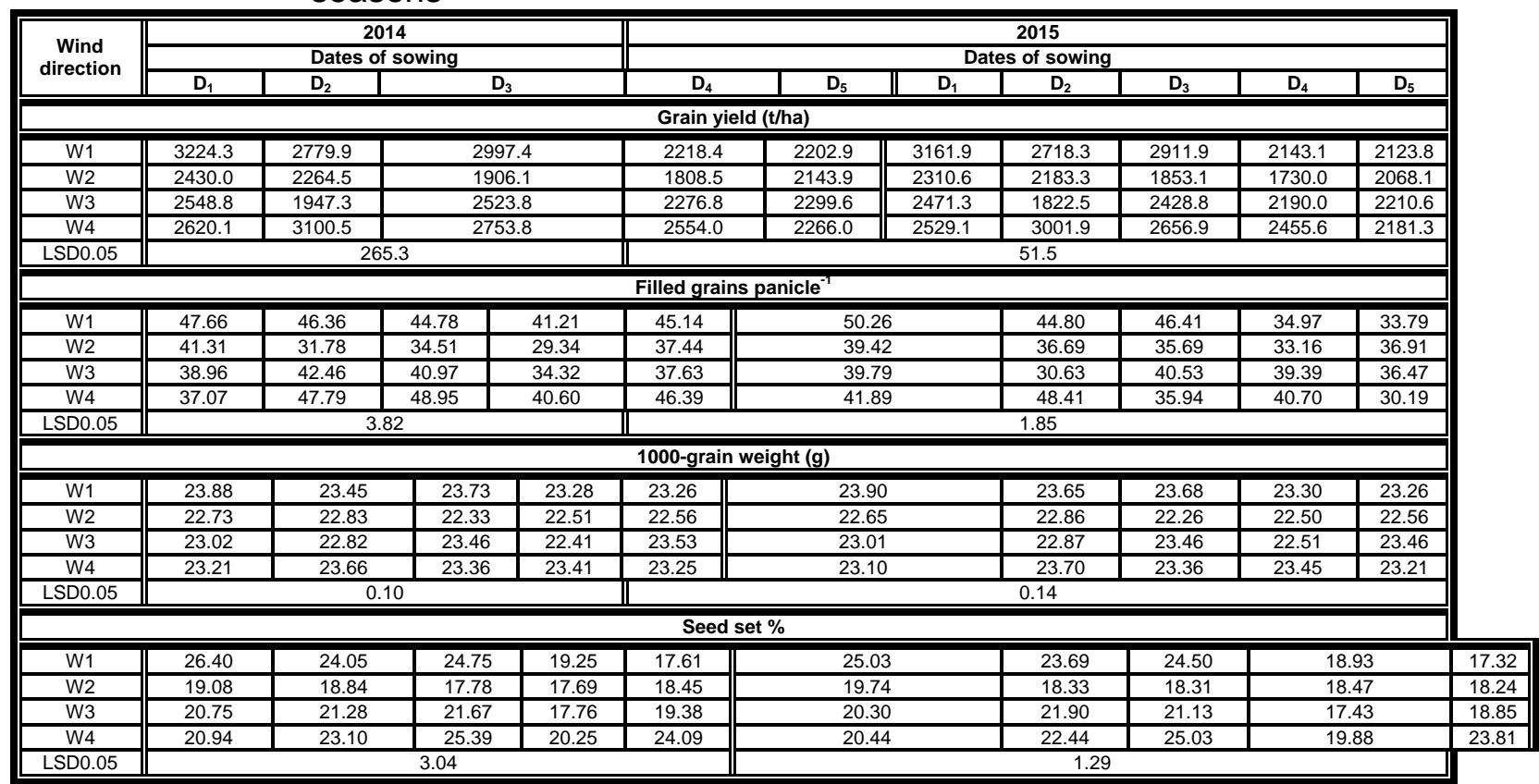


Table 8: Grain yield $\left(\mathrm{kg} \mathrm{ha}^{-1}\right)$, filled grains panicle ${ }^{-1}$, seed setting percentage (\%) and 1000-grain weight $(\mathrm{g})$ as affected by the interaction between supplementary pollination and wind direction in 2014 and 2015 seasons

\begin{tabular}{|c|c|c|c|c|}
\hline \multirow{2}{*}{ Wind direction } & \multicolumn{2}{|c|}{2014} & \multicolumn{2}{|c|}{2015} \\
\hline & $\mathrm{S}_{1}$ & $\mathrm{~S}_{2}$ & $\mathrm{~S}_{1}$ & $\mathrm{~S}_{2}$ \\
\hline \multicolumn{5}{|c|}{ Grain yield (t/ha) } \\
\hline$W_{1}$ & 2268.6 & 3100.6 & 2207.8 & 3015.8 \\
\hline$W_{2}$ & 1138.4 & 3082.8 & 1056.0 & 3002.0 \\
\hline$W_{3}$ & 1689.7 & 2948.8 & 1597.2 & 2852.0 \\
\hline $\mathrm{W}_{4}$ & 2135.7 & 3182.1 & 2037.4 & 3092.0 \\
\hline LSD 0.05 & \multicolumn{2}{|c|}{185.9} & \multicolumn{2}{|c|}{31.7} \\
\hline \multicolumn{5}{|c|}{ Filled grains panicle $^{-1}$} \\
\hline$W_{1}$ & 36.89 & 53.17 & 35.69 & 48.40 \\
\hline$W_{2}$ & 23.68 & 46.06 & 22.85 & 50.01 \\
\hline$W_{3}$ & 27.24 & 50.50 & 28.47 & 46.24 \\
\hline$W_{4}$ & 35.84 & 52.48 & 32.42 & 46.43 \\
\hline LSD 0.05 & \multicolumn{2}{|c|}{2.27} & \multicolumn{2}{|c|}{1.11} \\
\hline \multicolumn{5}{|c|}{ 1000-grain weight $(\mathrm{g})$} \\
\hline$W_{1}$ & 18.35 & 26.38 & 18.11 & 25.68 \\
\hline$W_{2}$ & 11.60 & 25.13 & 11.77 & 25.46 \\
\hline$W_{3}$ & 14.09 & 26.24 & 13.93 & 25.92 \\
\hline $\mathrm{W}_{4}$ & 18.51 & 27.00 & 17.86 & 26.78 \\
\hline LSD 0.05 & \multicolumn{2}{|c|}{2.14} & \multicolumn{2}{|c|}{0.77} \\
\hline \multicolumn{5}{|c|}{ Seed set $\%$} \\
\hline$W_{1}$ & 23.27 & 23.77 & 23.34 & 23.78 \\
\hline $\mathrm{W}_{2}$ & 22.18 & 23.01 & 22.11 & 23.01 \\
\hline$W_{3}$ & 22.51 & 23.59 & 22.57 & 23.56 \\
\hline$W_{4}$ & 23.09 & 23.67 & 23.13 & 23.59 \\
\hline LSD 0.05 & \multicolumn{2}{|c|}{0.05} & \multicolumn{2}{|c|}{0.08} \\
\hline
\end{tabular}


Table 9: Grain yield $\left(\mathrm{kg} \mathrm{ha}^{-1}\right)$, filled grains panicle ${ }^{-1}$, seed setting percentage (\%) and 1000-grain weight $(\mathrm{g})$ as affected by the interaction between supplementary pollination and date of sowing in 2014 and 2015 seasons

\begin{tabular}{|c|c|c|c|c|}
\hline \multirow{2}{*}{$\begin{array}{l}\text { Date of } \\
\text { sowing }\end{array}$} & \multicolumn{2}{|c|}{2014} & \multicolumn{2}{|c|}{2015} \\
\hline & $\mathrm{S}_{1}$ & $\mathrm{~S}_{2}$ & $\mathrm{~S}_{1}$ & $\mathrm{~S}_{2}$ \\
\hline \multicolumn{5}{|c|}{ Grain yield (t/ha) } \\
\hline$D_{1}$ & 2002.6 & 3408.9 & 1921.4 & 3315.0 \\
\hline $\mathrm{D}_{2}$ & 1793.7 & 3252.4 & 1705.7 & 3157.3 \\
\hline $\mathrm{D}_{3}$ & 1869.2 & 3221.4 & 1787.5 & 3137.8 \\
\hline$\overline{D_{4}}$ & 1432.3 & 2996.5 & 1354.1 & 2900.3 \\
\hline$D_{5}$ & 1942.7 & 2513.5 & 1854.4 & 2437.5 \\
\hline LSD 0.05 & \multicolumn{2}{|c|}{$\frac{1}{179.2}$} & \multicolumn{2}{|c|}{37.2} \\
\hline \multicolumn{5}{|c|}{ Filled grains panicle ${ }^{-1}$} \\
\hline$D_{1}$ & 30.79 & 51.70 & 31.82 & 53.86 \\
\hline $\mathrm{D}_{2}$ & 31.98 & 52.22 & 29.08 & 51.32 \\
\hline$D_{3}$ & 30.95 & 53.65 & 30.89 & 48.40 \\
\hline$\overline{D_{4}}$ & 25.12 & 47.61 & 26.03 & 48.08 \\
\hline$D_{5}$ & 35.71 & 47.58 & 31.49 & 37.19 \\
\hline LSD 0.05 & \multicolumn{2}{|c|}{2.75} & \multicolumn{2}{|c|}{1.31} \\
\hline \multicolumn{5}{|c|}{ 1000-grain weight $(\mathrm{g})$} \\
\hline$D_{1}$ & 16.51 & 27.05 & 16.16 & 26.95 \\
\hline$D_{2}$ & 16.19 & 27.45 & 15.95 & 27.23 \\
\hline$D_{3}$ & 16.21 & 28.49 & 16.51 & 27.98 \\
\hline$D_{4}$ & 12.76 & 24.72 & 12.70 & 24.66 \\
\hline$D_{5}$ & 16.52 & 23.24 & 15.78 & 23.33 \\
\hline LSD 0.05 & \multicolumn{2}{|c|}{2.40} & \multicolumn{2}{|c|}{0.97} \\
\hline \multicolumn{5}{|c|}{ Seed set $\%$} \\
\hline$\overline{D_{1}}$ & 22.87 & 23.55 & 22.85 & 23.47 \\
\hline$D_{2}$ & 22.66 & 23.72 & 22.78 & 23.76 \\
\hline$D_{3}$ & 22.93 & 23.51 & 22.91 & 23.46 \\
\hline$\overline{D_{4}}$ & 22.43 & 23.38 & 22.51 & 23.36 \\
\hline$D_{5}$ & 22.91 & 23.38 & 22.88 & 23.35 \\
\hline LSD 0.05 & \multicolumn{2}{|c|}{$\frac{1}{0.07}$} & \multicolumn{2}{|c|}{0.09} \\
\hline
\end{tabular}

From tables 10,11, 12, and 13 data show that the highest grain yield (t/ha, 3878.1 and $3752.5 \mathrm{~kg}$ ha, filled grains panicle-1 (56.34 and $58.44)$ and 1000 grain weight (24.00 and $24.02 \mathrm{~g}$ ) were produced by the combination between wind direction on (W1), first date of sowing (D1) and supplementary pollination(S2). The combination between wind direction W1, D1 and S2 followed W4, D2 and S2 then W1, D2 and S2 gave the highest values. The combination between W2, D3 and $\mathrm{S} 1$ recorded the lowest grain yield, filled grains panicle-1, seed set $\%$ and 1000-grain weight. 
Table 10: Grain yield $\left(\mathrm{kg} \mathrm{ha}^{-1}\right)$ as affected by the interaction among supplementary pollination, date of sowing and wind direction in 2014 and 2015 seasons

\begin{tabular}{|c|c|c|c|c|c|}
\hline \multirow{2}{*}{$\begin{array}{c}\text { Wind } \\
\text { direction }\end{array}$} & \multirow{2}{*}{$\begin{array}{l}\text { Date of } \\
\text { sowing }\end{array}$} & \multicolumn{2}{|c|}{2014} & \multicolumn{2}{|c|}{$\begin{array}{c}2015 \\
\text { Supplementary pollination }\end{array}$} \\
\hline & & $\mathrm{S}_{1}$ & $\mathrm{~S}_{2}$ & $\mathrm{~S}_{1}$ & $\mathrm{~S}_{2}$ \\
\hline$W_{1}$ & $\begin{array}{l}D_{1} \\
D_{2} \\
D_{3} \\
D_{4} \\
D_{5}\end{array}$ & $\begin{array}{l}2570.6 \\
2396.5 \\
2497.0 \\
1824.4 \\
2054.6\end{array}$ & $\begin{array}{l}3878.1 \\
3163.5 \\
3497.8 \\
2612.3 \\
2351.2\end{array}$ & $\begin{array}{l}2571.2 \\
2305.0 \\
2398.7 \\
1771.3 \\
1992.5\end{array}$ & $\begin{array}{l}3752.5 \\
3131.5 \\
3425.0 \\
2515.0 \\
2255.0\end{array}$ \\
\hline$W_{2}$ & $\begin{array}{l}D_{1} \\
D_{2} \\
D_{3} \\
D_{4} \\
D_{5}\end{array}$ & $\begin{array}{c}1752.0 \\
1099.7 \\
916.0 \\
520.2 \\
1404.3\end{array}$ & $\begin{array}{l}3108.1 \\
3429.4 \\
2896.2 \\
3096.8 \\
2883.6\end{array}$ & $\begin{array}{c}1591.2 \\
1021.5 \\
878.7 \\
457.5 \\
1331.2\end{array}$ & $\begin{array}{l}3030.0 \\
3345.0 \\
2827.5 \\
3002.0 \\
2805.0\end{array}$ \\
\hline$W_{3}$ & $\begin{array}{l}D_{1} \\
D_{2} \\
D_{3} \\
D_{4} \\
D_{5}\end{array}$ & $\begin{array}{l}1673.4 \\
1193.8 \\
1856.4 \\
1455.5 \\
2269.5\end{array}$ & $\begin{array}{l}3424.3 \\
2700.7 \\
3191.2 \\
3098.1 \\
2329.7\end{array}$ & $\begin{array}{l}1607.5 \\
1110.0 \\
1762.5 \\
1357.5 \\
2148.8\end{array}$ & $\begin{array}{l}3335.0 \\
2535.0 \\
3095.0 \\
3022.5 \\
2272.5\end{array}$ \\
\hline$W_{4}$ & $\begin{array}{l}D_{1} \\
D_{2} \\
D_{3} \\
D_{4} \\
D_{5} \\
\end{array}$ & $\begin{array}{l}2014.6 \\
2484.9 \\
2207.3 \\
1929.3 \\
2042.4 \\
\end{array}$ & $\begin{array}{l}3225.6 \\
3716.0 \\
3300.2 \\
3178.8 \\
2489.6 \\
\end{array}$ & $\begin{array}{l}1915.7 \\
2386.2 \\
2110.0 \\
1830.0 \\
1945.0 \\
\end{array}$ & $\begin{array}{l}3142.5 \\
3617.5 \\
3203.8 \\
3081.2 \\
2417.5 \\
\end{array}$ \\
\hline \multicolumn{2}{|c|}{ L.S.D. 0.05} & \multicolumn{2}{|c|}{366.9} & \multicolumn{2}{|c|}{73.5} \\
\hline
\end{tabular}


Table 11: Filled grains panicle ${ }^{-1}$ as affected by the interaction among supplementary pollination, date of sowing and wind direction in 2014 and 2015 seasons

\begin{tabular}{|c|c|c|c|c|c|}
\hline \multirow{2}{*}{$\begin{array}{l}\text { Wind } \\
\text { direction }\end{array}$} & \multirow{2}{*}{$\begin{array}{l}\text { Date of } \\
\text { sowing }\end{array}$} & \multicolumn{2}{|c|}{2014} & \multicolumn{2}{|c|}{2015} \\
\hline & & $\mathrm{S}_{1}$ & $\mathrm{~S}_{2}$ & $\mathrm{~S}_{1}$ & $\mathrm{~S}_{2}$ \\
\hline$W_{1}$ & $\begin{array}{l}D_{1} \\
D_{2} \\
D_{3} \\
D_{4} \\
D_{5}\end{array}$ & $\begin{array}{l}38.97 \\
37.46 \\
36.50 \\
30.42 \\
41.07\end{array}$ & $\begin{array}{l}56.34 \\
55.26 \\
53.06 \\
52.00 \\
49.21\end{array}$ & $\begin{array}{l}42.09 \\
36.62 \\
38.45 \\
30.07 \\
31.23\end{array}$ & $\begin{array}{l}58.44 \\
52.97 \\
54.37 \\
39.87 \\
36.35\end{array}$ \\
\hline$W_{2}$ & $\begin{array}{l}D_{1} \\
D_{2} \\
D_{3} \\
D_{4} \\
D_{5} \\
\end{array}$ & $\begin{array}{l}29.81 \\
21.21 \\
21.68 \\
17.36 \\
28.37\end{array}$ & $\begin{array}{l}52.82 \\
42.35 \\
47.34 \\
41.32 \\
46.50\end{array}$ & $\begin{array}{l}28.45 \\
21.83 \\
19.16 \\
16.22 \\
28.57\end{array}$ & $\begin{array}{l}50.38 \\
52.11 \\
52.22 \\
50.10 \\
45.21\end{array}$ \\
\hline$W_{3}$ & $\begin{array}{l}D_{1} \\
D_{2} \\
D_{3} \\
D_{4} \\
D_{5}\end{array}$ & $\begin{array}{l}27.07 \\
26.22 \\
27.91 \\
20.23 \\
34.76\end{array}$ & $\begin{array}{l}50.48 \\
58.71 \\
54.03 \\
48.42 \\
40.50\end{array}$ & $\begin{array}{l}27.02 \\
19.66 \\
30.82 \\
29.39 \\
35.50\end{array}$ & $\begin{array}{l}52.55 \\
41.60 \\
50.24 \\
40.38 \\
37.44\end{array}$ \\
\hline$W_{4}$ & $\begin{array}{l}D_{1} \\
D_{2} \\
D_{3} \\
D_{4} \\
D_{5}\end{array}$ & $\begin{array}{l}27.32 \\
43.03 \\
37.70 \\
32.49 \\
38.65\end{array}$ & $\begin{array}{l}46.81 \\
52.56 \\
60.19 \\
48.71 \\
54.12\end{array}$ & $\begin{array}{l}29.72 \\
38.21 \\
35.11 \\
28.42 \\
30.65\end{array}$ & $\begin{array}{l}54.05 \\
58.60 \\
36.76 \\
52.97 \\
29.74\end{array}$ \\
\hline \multicolumn{2}{|c|}{ L.S.D. 0.05} & \multicolumn{2}{|c|}{5.40} & \multicolumn{2}{|c|}{2.59} \\
\hline
\end{tabular}

Table 12: Seed setting percentage (\%) as affected by the interaction among supplementary pollination, date of sowing and wind direction in 2014 and 2015 seasons

\begin{tabular}{|c|c|c|c|c|c|}
\hline \multirow{3}{*}{$\begin{array}{c}\text { Wind } \\
\text { direction }\end{array}$} & \multirow{3}{*}{$\begin{array}{l}\text { Date of } \\
\text { sowing }\end{array}$} & \multicolumn{2}{|c|}{2014} & \multicolumn{2}{|c|}{2015} \\
\hline & & Supplen & Ilination & Supplen & Illination \\
\hline & & $\mathrm{S}_{1}$ & $\mathrm{~S}_{2}$ & $\mathrm{~S}_{1}$ & $\mathrm{~S}_{2}$ \\
\hline$W_{1}$ & $\begin{array}{l}D_{1} \\
D_{2} \\
D_{3} \\
D_{4} \\
D_{5} \\
\end{array}$ & $\begin{array}{l}21.88 \\
19.35 \\
20.06 \\
14.21 \\
16.27 \\
\end{array}$ & $\begin{array}{l}30.83 \\
28.75 \\
29.09 \\
24.29 \\
18.95\end{array}$ & $\begin{array}{l}20.76 \\
19.07 \\
20.73 \\
14.34 \\
15.64\end{array}$ & $\begin{array}{l}29.29 \\
28.32 \\
28.27 \\
23.51 \\
18.99 \\
\end{array}$ \\
\hline$W_{2}$ & $\begin{array}{l}D_{1} \\
D_{2} \\
D_{3} \\
D_{4} \\
D_{5} \\
\end{array}$ & $\begin{array}{c}14.01 \\
11.38 \\
10.64 \\
9.87 \\
11.66 \\
\end{array}$ & $\begin{array}{l}24.15 \\
25.85 \\
21.91 \\
25.52 \\
25.25 \\
\end{array}$ & $\begin{array}{c}13.87 \\
11.76 \\
12.04 \\
9.67 \\
11.54 \\
\end{array}$ & $\begin{array}{l}25.61 \\
24.90 \\
24.59 \\
27.28 \\
24.94 \\
\end{array}$ \\
\hline$W_{3}$ & $\begin{array}{l}D_{1} \\
D_{2} \\
D_{3} \\
D_{4}\end{array}$ & $\begin{array}{l}14.48 \\
12.81 \\
14.72 \\
10.43\end{array}$ & $\begin{array}{l}27.02 \\
20.75 \\
28.61 \\
25.10\end{array}$ & $\begin{array}{l}14.68 \\
13.07 \\
14.62 \\
10.63\end{array}$ & $\begin{array}{l}25.92 \\
30.72 \\
27.63 \\
24.24\end{array}$ \\
\hline
\end{tabular}




\begin{tabular}{||c|c||c|c||c|c||} 
& $D_{5}$ & 18.00 & 20.76 & 16.64 & 21.06 \\
\hline \multirow{3}{*}{$W_{4}$} & $D_{1}$ & 15.67 & 26.20 & 15.33 & 25.54 \\
& $D_{2}$ & 20.77 & 25.44 & 19.89 & 24.99 \\
& $D_{3}$ & 19.43 & 31.36 & 18.64 & 31.42 \\
& $D_{4}$ & 16.52 & 23.98 & 16.17 & 23.60 \\
& $D_{5}$ & 20.16 & 28.03 & 19.29 & 28.33 \\
\hline \multicolumn{2}{|c||}{4.52} \\
\hline \multicolumn{2}{|c|}{ L.S.D. 0.05 }
\end{tabular}

Table 13: 1000-grain weight $(\mathrm{g})$ as affected by the interaction among wind direction, date of sowing and supplementary pollination in 2014 and 2015 seasons.

\begin{tabular}{|c|c|c|c|c|c|}
\hline \multirow{2}{*}{$\begin{array}{l}\text { Wind } \\
\text { direction }\end{array}$} & \multirow{2}{*}{$\begin{array}{l}\text { Date of } \\
\text { sowing }\end{array}$} & \multicolumn{2}{|c|}{2014} & \multicolumn{2}{|c|}{2015} \\
\hline & & $\mathrm{S}_{1}$ & $\mathrm{~S}_{2}$ & $\mathrm{~S}_{1}$ & $\mathrm{~S}_{2}$ \\
\hline$W_{1}$ & $\begin{array}{l}D_{1} \\
D_{2} \\
D_{3} \\
D_{4} \\
D_{5} \\
\end{array}$ & $\begin{array}{l}23.75 \\
23.12 \\
23.50 \\
22.95 \\
23.05\end{array}$ & $\begin{array}{l}24.00 \\
23.77 \\
23.97 \\
23.62 \\
23.40 \\
\end{array}$ & $\begin{array}{l}23.77 \\
23.42 \\
23.50 \\
23.00 \\
23.02 \\
\end{array}$ & $\begin{array}{l}24.02 \\
23.87 \\
23.87 \\
23.60 \\
23.50 \\
\end{array}$ \\
\hline$W_{2}$ & $\begin{array}{l}D_{1} \\
D_{2} \\
D_{3} \\
D_{4} \\
D_{5}\end{array}$ & $\begin{array}{l}22.47 \\
22.22 \\
22.15 \\
21.87 \\
22.17\end{array}$ & $\begin{array}{l}23.00 \\
23.45 \\
22.52 \\
23.15 \\
22.95\end{array}$ & $\begin{array}{l}22.45 \\
22.20 \\
21.92 \\
21.87 \\
22.10\end{array}$ & $\begin{array}{l}22.85 \\
23.52 \\
22.60 \\
23.12 \\
22.95\end{array}$ \\
\hline$W_{3}$ & $\begin{array}{l}D_{1} \\
D_{2} \\
D_{3} \\
D_{4} \\
D_{5}\end{array}$ & $\begin{array}{l}22.17 \\
21.97 \\
22.92 \\
22.02 \\
23.47\end{array}$ & $\begin{array}{l}23.87 \\
23.67 \\
24.00 \\
22.82 \\
23.60\end{array}$ & $\begin{array}{l}22.17 \\
22.10 \\
23.05 \\
22.12 \\
23.42\end{array}$ & $\begin{array}{l}23.85 \\
23.65 \\
23.87 \\
22.90 \\
23.50 \\
\end{array}$ \\
\hline$W_{4}$ & $\begin{array}{l}D_{1} \\
D_{2} \\
D_{3} \\
D_{4} \\
D_{5}\end{array}$ & $\begin{array}{l}23.10 \\
23.32 \\
23.15 \\
22.90 \\
22.97\end{array}$ & $\begin{array}{l}23.32 \\
24.00 \\
23.57 \\
23.92 \\
23.52\end{array}$ & $\begin{array}{l}23.03 \\
23.40 \\
23.20 \\
23.07 \\
22.98\end{array}$ & $\begin{array}{l}23.17 \\
24.00 \\
23.52 \\
23.82 \\
23.45\end{array}$ \\
\hline \multicolumn{2}{|c|}{ L.S.D. 0.05} & \multicolumn{2}{|c|}{0.13} & \multicolumn{2}{|c|}{0.19} \\
\hline
\end{tabular}

REFERENCES

Abdel-Hafez, A. G.; M.I. Abo-Youssef; E. E. El-Sharef and H. S. Hamad (2005). Effect of sowing date and growth regulators on rice hybrid seed quality and seedling characters. Eleventh 
Conference of Agronomy, Agron. Dept., Fac. Agric., Assiut Univ., (15-16): 223-233.

Duncan, D.B. (1955). Multiple range and multiple F. test. Biometrics. 11:1-42.

Gab Allah, M. M. (2004). Studies on hybrid rice seed production. M.Sc. Fac. Agric. Kafr El-Sheikh Tanta Univ. 110.

Gomez, K.A. and A.A Gomez (1984). Statistical procedures for agricultural research. $2^{\text {nd }}$ Ed. John Wiley and Sons, New Yourk, USA.

Huang, P.; K. Maruyama; H.L. Shama and S.S. Virmani (1998). Advances in hybrid rice seed production technology. New developments and prospects, IRRI.: 67-70.

IRRI, (International Rice Research Institute) (1996). Program report for 1998: Los Banos (Phillippines). International Rice Research Institute.

Jarughula, S.; A. Rang; T.S. Bharaj; S. Jarughula and A. Rang (2002). Effect of staggered sowing of restorer lines and doses of gibberellic acid on seed production in hybrid rice. Crop Improvement, 29 (1): 24-27.

Viraktamath, B.C.; H.M. Vijayakumar; M.S. Ramesha; S. Singh and K. Krishnaia (1998). Effect of $\mathrm{GA}_{3}$ doses on seed yield, seed set and other traits in CMS multiplication and hybrid seed production. Rice progress Report 41-43.

(Shanker Lal (2010). Guidelines for seed production of hybrid rice. National food security mission. Government of India, Ministry of Agric. Department of Agric. \&cooperation pp 1-35.

Virmani, S.S. and H.L. Sharma (1993). Manual for hybrid rice seed production. IRRI. P.O. Box. 933, 1099 Manila Philippines pp: 157.

Virmani, S.S. C.X. Mao; R.S. Toledo; M. Hossain and A. Janaiah (2002b). Hybrid rice seed production technology and its impact on seed industries and rural employment opportunities in Asia. IRRI. 113.

Virmani, S. S (2003) Advances in hybrid rice research and development in the tropics. Hybrid rice for food security, Poverty Alleviation, and Environmental Protection. IRRI. P 7-20. 


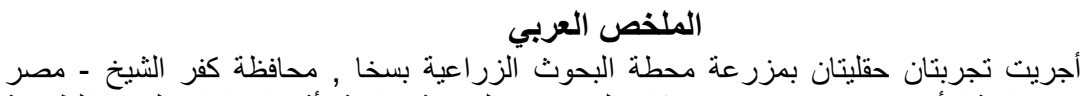

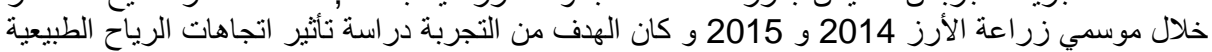

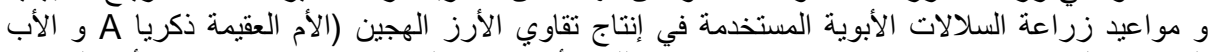

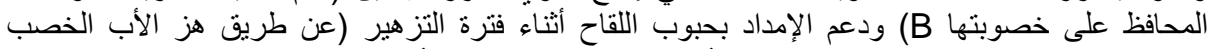

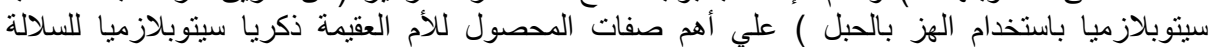
(Sakha1A/Sakha1B) مصري3 بالإضافة الي هجن مبشرة أخري).

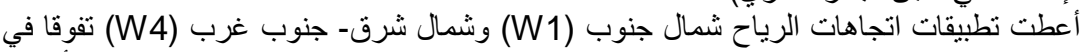

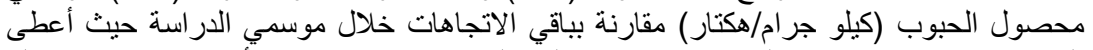

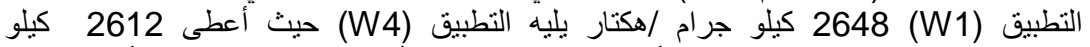

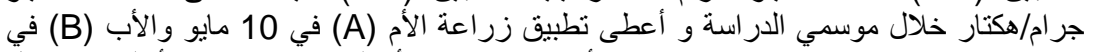

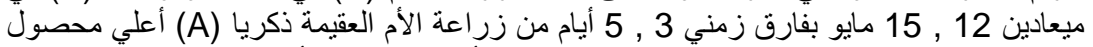

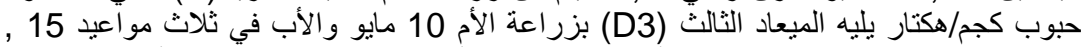

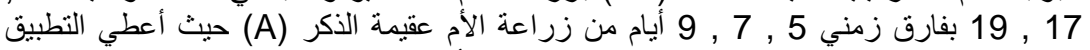
2662 كجم /هكتار تلاه التطبيق (D3) الدراسة.

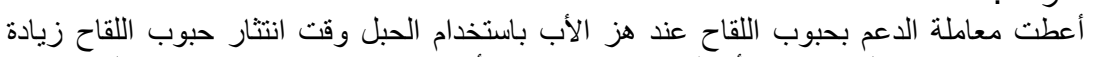

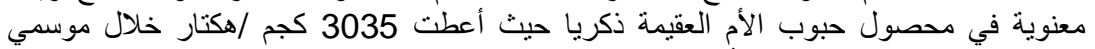

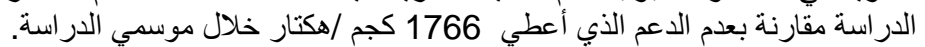

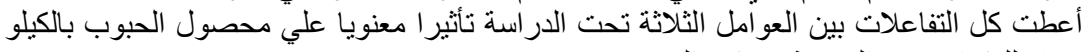
جر ام للاكتار تحت الداعلات استة في كلا الموسمين.

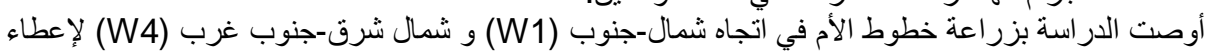

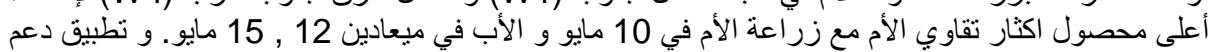

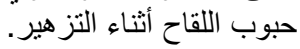

